\title{
Erratum to: 12th international congress of inborn errors of metabolism, 3rd-6th September, 2013
}

\author{
Jaime Campistol • Antonia Ribes
}

Published online: 28 August 2014

(C) SSIEM 2014

\section{Erratum to: J Inherit Metab Dis}

DOI 10.1007/s10545-014-9733-4

In the original publication Antonia Ribes was incorrectly assigned to the same institution as Jaime Campistol; in addition, her e-mail address was rendered incorrectly. The correct affiliation and e-mail address are given here.

Antonia Ribes

Sección de Errores Congénitos del Metabolismo-IBC,

Servicio de Bioquímica y Genética Molecular,

Hospital Clinic

Barcelona

Spain

e-mail: aribes@clinic.ub.es

The online version of the original article can be found at http://dx.doi.org/ 10.1007/s10545-014-9733-4.

J. Campistol $(\bowtie)$

Neurology Department, Hospital Sant Joan de Deu, Barcelona, Spain

e-mail: Campistol@hsjdbcn.org

A. Ribes

Sección de Errores Congénitos del Metabolismo-IBC, Servicio de Bioquímica y Genética Molecular, Hospital Clinic, Barcelona, Spain e-mail: aribes@clinic.ub.es 